\title{
Patryk Mamczur
}

Uniwersytet JaGIeLLoŃSKI W Krakowie

\section{Co począć z Beatlesami? Metodologia muzykologii wobec muzyki rockowej}

\section{Wstęp}

Badania nad muzyką rockową (i, szerzej, popularną) mają w Polsce stosunkowo krótką historię. Ze względu na złożoność zjawiska pozostają one wybitnie interdyscyplinarne, jednak wciąż brak u nas wyspecjalizowanych ośrodków skupiających się wyłącznie na tzw. popular music studies, a każda z nauk - m.in. kulturoznawstwo, socjologia, literaturoznawstwo, językoznawstwo i historia - rozpatruje muzykę popularną na własny sposób, korzystając z odrębnych narzędzi i zwracając uwagę na różne aspekty tego zjawiska. Tymczasem muzykologia, która teoretycznie powinna być zainteresowana każdym rodzajem muzyki, wciąż podchodzi do rocka i muzyki popularnej z pewną niechęcią. Problem ten w syntetyczny sposób przedstawił w swoim artykule Jakub Kasperski:

\footnotetext{
[...] przed muzykologami pragnącymi podjąć studia nad muzyką popularną stają dwie zasadnicze trudności: po pierwsze, uwarunkowania historyczne, które sprawiają, że muzykologia z trudem przyjmuje fakt, iż muzyka, jej kanony i wartości mogą wynikać z uwarunkowań społecznych, a nie z tylko
} 
z immanentnych właściwości muzyki; po drugie zaś problemy natury metodologicznej ${ }^{1}$.

Nie chcąc wdawać się $\mathrm{w}$ rozważania natury estetycznej (ale i mając świadomość, że w ostatnich latach muzykologia polska otwiera się na twórczość popularną), skupię się w poniższym artykule właśnie na owych, nierozwiniętych przez Kasperskiego, problemach natury metodologicznej.

Interesować mnie będą głównie trzy pytania badawcze: jakie są podstawowe różnice między przedmiotem badań „klasycznej muzykologii” a muzyką rockową? Które narzędzia badawcze wykorzystywane w muzykologii są nieadekwatne w obliczu muzyki rockowej (i czy można je do tejże muzyki dostosować)? W jaki sposób badania muzykologiczne mogą przyczynić się do lepszego poznania muzyki rockowej? Ze względu na wczesny etap tego typu rozważań metodologicznych w Polsce oraz ograniczenia objętościowe artykułu nie będzie możliwe całościowe, wyczerpujące potraktowanie problemu. Tekst ma raczej charakter przyczynkarski - uwaga zostanie zwrócona na najważniejsze problemy oraz te aspekty badań, w których rozdźwięk między tradycyjnie pojmowaną muzykologią a muzyką rockową wydaje się największy.

Aby nie poprzestać na czysto teoretycznych rozważaniach, konieczne jest ilustrowanie problemów badawczych konkretnymi przykładami. Rezerwuarem źródeł muzycznych będzie dla mnie amerykańska i brytyjska muzyka rockowa $\mathrm{z}$ lat 6o. XX wieku (ze sporadycznymi „wychyleniami” do dekad poprzedniej i następnej). Taki właśnie wybór podyktowany jest dużą różnorodnością charakteryzującą twórczość owego okresu i jej istotną rolą w anglosaskiej (a więc dominującej) literaturze przedmiotu, ale też osobistymi zainteresowaniami badawczymi autora. Kilkukrotnie będę się także odnosić - ze względu na jej rolę w kształtowaniu rocka - do muzyki bluesowej. Z kolei pojawiający się w tytule artykułu Beatlesi służą nie tylko jako „wytrych”, ale też w istocie stanowią najistotniejszą część bazy źródłowej. Baza ta uzupełniona została przez istniejące opracowania, głównie pióra zachodnich uczonych, którzy w kwestii metodologii badań muzyki popularnej poczynili już znaczące postępy. Szczególnie często będę nawiązywać do myśli

1 J. Kasperski, Tożsamość muzykologii w perspektywie badań nad muzyka popularną, [w:] Kultura popularna w społeczeństwie współczesnym. Teoria i rzeczywistość, red. J. Drozdowicz, M. Bernasiewicz, Kraków 2010, s. 272. 
tych badaczy, których prace pozostają w Polsce mniej znane, a więc np. Johna Covacha.

Konieczne jest jeszcze jedno wyjaśnienie: skąd „muzyka rockowa” w tytule artykułu i w powyższych rozważaniach. Po pierwsze, zdecydowanie niewłaściwe wydaje się sformułowanie „muzyka rozrywkowa”, które - nie tylko w rozumieniu powszechnym, ale i w definicji słownikowej - posiada negatywne konotacje ${ }^{2}$. Po drugie, w naszym przypadku niezbyt odpowiednia byłaby też etykieta „muzyka popularna” - to, co prawda, sformułowanie powszechnie stosowane w literaturze przedmiotu, niekojarzące się tak negatywnie jak „muzyka rozrywkowa”, a ponadto odnoszące nas niejako bezpośrednio do popular music studies; jest to jednak termin niezwykle pojemny i, chcąc uniknąć dywagowania na zbyt wysokim poziomie ogólności, konieczne jest w ograniczonym objętościowo artykule skonkretyzowanie przedmiotu badań. Stąd właśnie zwrócenie się ku muzyce rockowej - kategorii węższej, bardziej spójnej, poddającej się syntetycznemu uchwyceniu, a także odpowiedniej dla wzmiankowanego wyżej rezerwuaru źródeł muzycznych. Warto jednak zaznaczyć, że szereg wyciąganych przeze mnie w tym artykule wniosków odnosić się będzie również do muzyki popularnej jako całości.

\section{Budowa formalna}

Na początku zmagań $\mathrm{z}$ analizą muzyki rockowej napotykamy na zasadniczy problem - chodzi o rozdźwięk między muzyką poważną a rockową w kwestii zapisu muzycznego. Jedną z cech tzw. muzyki poważnej jest bowiem, jak to określił Wojciech Siwak, literalność. Zapisane zostają nie tylko wysokość dźwięku czy czas jego trwania, ale też np. ornamentyka. Nawet praktyka improwizacji - radykalnie, jak by się wydawało, zrywająca ze wspomnianą literalnością - zwykle zostaje poddana szeregowi zasad. Przedmiotem badań muzykologicznych jest w zdecydowanej większości przypadków utwór zapisany za pomocą systemu nutowego ${ }^{3}$. Tymczasem w muzyce rockowej sytuacja jest zu-

2 "Rozrywkowy” to „służący rozrywce, zwłaszcza łatwej, niewymagającej wysiłku umysłowego"; cyt. za: Słownik Języka Polskiego PWN, [online] sjp.pwn.pl/sjp/rozrywkowy;2517181.html [dostęp: 30.11.2016].

3 W. Siwak, Estetyka rocka, Warszawa 1993, s. 9; A.F. Moore, Rock. The Primary Text, Ashgate 2001, s. 34; G. Piotrowski, Zrozumieć krzyk. W stronę muzykologii rocka, [w:] A po co nam rock? Między dusza a ciałem, red. W.J. Burszta, M. Ry- 
pełnie odmienna - partytury stanowią rzadkość, a jeśli już istnieją, to najczęściej mają charakter wtórny (tj. powstają już po zarejestrowaniu utworu, zwykle dla potrzeb chcących go wykonać entuzjastów muzyki). W związku $\mathrm{z}$ tym należy $\mathrm{w}$ badaniach podchodzić do nich $\mathrm{z}$ niezwykłą ostrożnością i traktować w najlepszym wypadku jako źródła drugorzędne, podczas gdy pierwszorzędnymi będą same nagrania muzyczne (a w niektórych wypadkach wykonania na żywo) ${ }^{4}$. Sytuacja ta wynika m.in. z korzeni anglosaskiej muzyki rockowej, a więc z bluesa czy folku, których estetyka związana była zawsze z przekazem ustnym (a co za tym idzie, także z pewną wariacyjnością kolejnych wykonań)5.

Do kolejnej rozbieżności dochodzi w kwestii struktury formalnej utworów rockowych, do badania której dawna muzykologiczna systematyka przydać się może jedynie w niewielkim stopniu. Jeśli spróbujemy posłużyć się podręcznikowym podziałem form muzycznych, to stwierdzić będziemy musieli, że znaczna część muzyki rockowej (a także, szerzej, popularnej) - poza naprawdę nielicznymi wyjątkami - to pieśni. Nie byłoby to oczywiście stwierdzenie błędne, jednak z pewnością zbyt ogólnikowe i dla naszych potrzeb niewystarczające.

Mając na uwadze zaznaczone problemy, naukowcy zajmujący się muzyką popularną wypracowali przez szereg lat odrębne, jeszcze nie do końca usystematyzowane spojrzenie na kwestię budowy formalnej utworów. Spróbuję je dla naszych potrzeb uporządkować (sięgając przy tym głównie do prac Covacha i Allana F. Moorea). Zacząć należy od wymienienia i opisania poszczególnych części składowych kompozycji popularnej. W terminologii angielskiej są to: verse, refrain, chorus, bridge, introduction, coda (in. playout), solo.

Verse to nic innego jak zwrotka, a więc pojawiająca się kilkukrotnie cząstka utworu, różniąca się od refrenu i występująca z nim zamiennie, o powtarzalnej warstwie muzycznej, ale zmieniającym się (poza wyjątkami) tekście. Pewien problem sprawić nam może rozróżnienie refrain i chorus, jako że obie te części tłumaczone są zwykle na język polski jako „refren”. Dla ułatwienia systematyki oraz zbliżenia polskiej terminologii do tej używanej przez badaczy anglosaskich, proponuję tłumaczyć refrain jako „powtórzenie”, a chorus jako

chlewski, Warszawa 2003, s. 46; P. Tagg, Analysing Popular Music. Theory, Method and Practice, „Popular Music” 2 (1982), s. 41.

4 A.F. Moore, dz. cyt., s. 34-35.

5 W. Siwak, dz. cyt., s. 10. 
właściwy „refren”6. Obie te części charakteryzują się powtarzalnością w warstwie muzycznej oraz tekstowej, a tym, co je różni, jest długość trwania oraz - przede wszystkim - miejsce, jakie zajmują w utworze. Czas trwania refrenu (chorus) jest niejednokrotnie taki sam, jak czas trwania zwrotki, a podstawową funkcją tej części jest tworzenie dla zwrotek kontrastu (stąd nie tylko częste zmiany melodii, ale też np. rytmu, co zostanie przeanalizowane na dalszych stronach) oraz przedstawienie "tematu”, głównej myśli muzycznej utworu. Tymczasem powtórzenie (refrain) jest zwykle krótsze, np. czterotaktowe, i pozostaje w ścisłym związku ze zwrotką, występując na jej końcu stąd posługujemy się najczęściej sformułowaniem verse with refrain (zwrotka z powtórzeniem) ${ }^{7}$.

\begin{tabular}{|c|c|c|}
\hline $0: 00-0: 13$ & Refren (8 taktów) & "She loves you, yeah, yeah, yeah..." \\
\hline \multirow[t]{2}{*}{$0: 13-0: 38$} & Zwrotka (16 taktów) & „You think you’ve lost your love...” \\
\hline & z powtórzeniem & "She says she loves you...” \\
\hline $0: 38-1: 04$ & $\begin{array}{l}\text { Zwrotka ( } 16 \text { taktów) } \\
\text { Z powtórzeniem }\end{array}$ & $\begin{array}{l}\text { "She said you hurt her so..." } \\
\text { "She says she loves you..." }\end{array}$ \\
\hline 1:04-1:16 & Refren (8 taktów) & "She loves you, yeah, yeah, yeah..." \\
\hline \multirow[t]{2}{*}{ 1:16-1:42 } & Zwrotka (16 taktów) & „You know it’s up to you...” \\
\hline & z powtórzeniem & „Because she loves you...” \\
\hline $1: 42-1: 55$ & Refren (8 taktów) & „She loves you, yeah, yeah, yeah...” \\
\hline 1:55-2:21 & Zakończenie (14 taktów) & „With a love like that...” \\
\hline
\end{tabular}

Przykład 1. Budowa formalna utworu She Loves You The Beatles. Wykorzystany został sposób opisu budowy formalnej utworów rockowych stosowany m.in. przez Covacha. Uwagi: pierwsza ekspozycja refrenu różni się nieco od późniejszych (drugiej i trzeciej); różnią się także (choć nieznacznie) kolejne powtórzenia (refrains) na końcach zwrotek; zakończenie ma charakter przedłużonego refrenu.

Różnicę tę można zaobserwować w jednej z wczesnych kompozycji Beatlesów, She Loves You (patrz: przykład 1.), gdzie jednocześnie występują powtórzenie - mające ścisły związek ze zwrotką, będące jego dokończeniem - oraz refren niosący główną myśl utworu, kontrastujący ze zwrotką. Należy jednak pamiętać o tym, że wszelkie tego typu roz-

6 Wszystkich mających pomysł na inne tłumaczenie tego terminu uprzejmie proszę o kontakt.

7 A.F. Moore, dz. cyt., s. 52, 223, 225, 227; J. Covach, What's That Sound. An Introduction to Rock and Its History, New York-London 2009, s. 11, 101-105. 
różnienia mają charakter arbitralny i w pewnych przypadkach określenie, czy mamy do czynienia ze zwrotką i powtórzeniem, czy ze zwrotką i refrenem, będzie kwestią dyskusyjną. Warto też na marginesie wspomnieć, że w niektórych utworach popularnych pojawia się część zwana pre-chorus (przedrefrenem), stanowiąca krótki łącznik między zwrotką a refrenem - wiele wskazuje na to, że może być to (przynajmniej w niektórych wypadkach) ewolucja opisanego przed chwilą schematu zwrotka-powtórzenie-refren. Temat ten jednak wymaga zgłębienia.

Bridge ${ }^{8}$ pojawia się w środku utworu (np. po dwukrotnej ekspozycji zwrotki) i ma stanowić odmianę dla powtarzalnych zwrotek i refrenów, swego rodzaju moment odprężenia - dlatego też zwykle pojawia się tylko raz (znanym wyjątkiem jest repryzowa forma AABA, którą wkrótce przeanalizujemy). Podobnie jednorazowy charakter mają też oczywiście wstęp (intro, introduction) oraz zakończenie (coda, playout). To ostatnie nierzadko zyskuje formę zwaną fade-out (wyciszenie), w której brak jest wyraźnej kadencji, a utwór kończy stopniowe wyciszanie trwającej melodii. Na odrębną uwagę zasługują przerywniki pozbawione partii wokalnej, często $\mathrm{w}$ formie instrumentalnego, wirtuozowskiego solo, które jednak w większości wypadków opierają się na materiale pochodzącym ze zwrotki, refrenu czy bridge'a'.

Po opisaniu części składowych piosenki właściwe wydaje się przejście do wyszczególnienia podstawowych form muzycznych w rocku. Jedną z najważniejszych (oraz szczególnie istotnych z perspektywy historycznego rozwoju rocka) jest forma bluesowa. I choć określenie to nie jest jednoznaczne, najczęściej rozumiemy pod tym terminem blues 12-taktowy. Takty owe podzielić można na 3 frazy (po 4 takty każda), gdzie fraza pierwsza i druga zwykle powtarzają ten sam tekst (czasem z drobną zmianą) i noszą nazwę „zawołania” (call), ew. „zawołania” i „zawołania powtórnego" (call and repetition), natomiast fraza trzecia stanowi dokończenie myśli, tzw. „konkluzję” (conclusion). Ów 12-taktowy schemat powtarza się w ciągu jednego utworu wielokrotnie, zwykle z innym tekstem (choć zdarza się na przykład, że konkluzja jest taka

8 Nazwa angielska zadomowiła się w Polsce już na tyle, że chyba nie ma potrzeby korzystania z dość sztucznych, bezpośrednich tłumaczeń pokroju „mostka”. Pojawia się też czasem określenie „łącznik”, ale z kolei ono może niepotrzebnie kierować nasze myśli ku muzyce poważnej (np. formie sonatowej).

9 A.F. Moore, dz. cyt., s. 52-53, 223. 
sama ${ }^{10}$. W przypadku początkowych wersów Got My Mojo Working ${ }^{11}$ Muddy'ego Watersa zawołanie stanowi „Got my mojo workin', but it just don't work on you" (powtórzone dwukrotnie), natomiast konkluzja to „I wanna love you so bad, I don't know what to do". Z ową formą związany jest także charakterystyczny pochód akordów, który zostanie przeanalizowany w następnej części artykułu.

Kolejną formą, która wiodła prym w muzyce popularnej przed pojawieniem się rock and rolla, ale także miała ogromny wpływ na późniejszą twórczość, np. Beatlesów, jest 32-taktowy schemat z Tin Pan Alley ${ }^{12}$, zwany też często formą AABA. Owe 32 takty dzielimy na 4 frazy (8-taktowe), gdzie frazy 1., 2. i 4. są do siebie podobne (zwrotki lub zwrotki z powtórzeniem), natomiast fraza 3. ma charakter kontrastujący (bridge ${ }^{13}$ ). W praktyce kompozytorskiej często okazywało się, że 32 takty to zbyt mało, by stworzyć odpowiednio długą kompozycję, dlatego też stosowano powtórzenie schematu - pełne (co w efekcie dawało formę AABA AABA..., jak w przypadku Hey Good Lookin'14 Hanka Williamsa) lub tylko częściowe (np. AABA BA, jak w Blueberry Hill15 Fatsa Domino) ${ }^{16}$.

$\mathrm{Z}$ czasem dominującą stała się forma zwrotkowo-refrenowa. O ile nie ma konieczności ponownego wyjaśniania różnic między zwrotką a refrenem, o tyle warto zauważyć, że forma ta w niektórych opracowaniach występuje $\mathrm{w}$ dwóch podtypach (zwłaszcza u lubiącego wyraźne podziały formalne Covacha). Pierwszy z nich w nomenklaturze anglosaskiej zwany jest simple verse-chorus form (prosta forma zwrotkowo-refrenowa) i charakteryzuje się użyciem tego samego schematu rytmiczno-melodycznego zarówno dla zwrotek, jak i dla refrenów ${ }^{17}$. W przypadku wielu utworów, zwłaszcza tych rockandrollowych,

10 J. Covach, dz. cyt., s. 98-99; W. Siwak, dz. cyt., s. 12; A. Schmidt, Historia jazzu, t. 1, Warszawa 1988, s. 155-157.

11 Muddy Waters, Got My Mojo Working, muz. i tekst P. Foster, Chess Records 1956.

12 Zwyczajowa nazwa fragmentu West 28th Street na nowojorskim Manhattanie, gdzie pod koniec XIX oraz w pierwszej połowie XX wieku swoją siedzibę miał szereg producentów muzycznych i kompozytorów tworzących zbliżone do siebie, powtarzalne, ale jednocześnie dobrze sprzedające się utwory.

13 Zwany także middle eight - „środkowa ósemka”.

14 Hank Williams, Hey, Good Lookin', muz. i tekst C. Porter, MGM 1951.

15 Fats Domino, Blueberry Hill, muz. i tekst V. Rose/L. Stock/A. Lewis, Imperial Records 1956.

16 W. Siwak, dz. cyt., s. 11-12; J. Covach, dz. cyt., s. 105-107.

17 J. Covach, dz. cyt., s. 101-103. 
owym powtarzalnym schematem może być przywoływany już 12-taktowy blues; dzieje się tak np. w Johnny B. Goode ${ }^{18}$ Chucka Berry’ego, gdzie zmienny tekst zwrotek i powtarzalny refren wyśpiewywane są w oparciu o ten sam bluesowy pochód akordów. Drugim, bardziej urozmaiconym podtypem piosenek zwrotkowo-refrenowych jest contrasting verse-chorus form (kontrastowa forma zwrotkowo-refrenowa), gdzie - jak łatwo się domyślić - brzmienie zwrotek i refrenów jest odmienne ${ }^{19}$. Przykład takiego utworu może stanowić inna kompozycja Berry'ego - Rock and Roll Music ${ }^{20}$. Co ciekawe, i tutaj wykorzystano schemat bluesowy, tym razem jedynie jako podstawę refrenu, podczas gdy zwrotki bazują na innym materiale.

Na samym końcu pochylimy się na chwilę nad formą, jak się wydaje, najmniej skomplikowaną. Mowa o prostej formie zwrotkowej (simple verse form). Utwory tego typu (np. Paint It Black ${ }^{21}$ Rolling Stonesów), oparte na powtarzalnym pochodzie akordów, składają się wyłącznie ze zwrotek (czasem zwrotek z powtórzeniami, tj. refrains), bez wyróżniającego się refrenu czy bridge'a ${ }^{22}$. Nie bez podstaw byłoby twierdzenie, że odmianą prostej formy zwrotkowej są klasyczne utwory bluesowe (tu jednak przeanalizowane osobno, głównie ze względów chronologicznych).

Jak słusznie zauważa Moore, wymienione wyżej formy, zwłaszcza takie jak prosta forma zwrotkowa, często charakteryzują się dużą powtarzalnością ${ }^{23}$. Kolejni twórcy starają się więc urozmaicać je na różne sposoby - część z tych sposobów przeanalizuję na kolejnych stronach artykułu.

\section{Melodyka i harmonika}

Harmonika oraz melodyka w muzyce rockowej (a już zwłaszcza w całej muzyce popularnej) pozostają bardzo zróżnicowane i choć wśród badaczy pojawiają się różne pomysły ich klasyfikacji, to wciąż daleko

18 Chuck Berry, Johnny B. Goode, muz. i tekst Ch. Berry, Chess 1958.

19 J. Covach, dz. cyt., s. 104-105.

20 Chuck Berry, Rock and Roll Music, muz. i tekst Ch. Berry, Chess 1957.

21 The Rolling Stones, Paint It Black, muz. i tekst M. Jagger/K. Richards, Decca 1966.

22 J. Covach, dz. cyt., s. 103-104; A.F. Moore, dz. cyt.., s. 55.

23 A.F. Moore, dz. cyt., s. 56. 
jest do konsensusu ${ }^{24}$. W tej części zauważę więc jedynie pewne ogólne, powtarzające się cechy oraz - podobnie jak to uczyniłem w przypadku formy - zaprezentuję kilka utartych schematów harmoniczno-melodycznych.

Po raz kolejny zaczynamy od korzeni całej muzyki rockowej, a więc od bluesa. Zostało już wspomniane, że 12-taktowy schemat formalny bluesa wiąże się $\mathrm{w}$ ścisły sposób $\mathrm{z}$ równie powtarzalnym schematem akordowym. Bluesowa harmonika prezentuje się w sposób następujący: taktom 1-4 (a więc całej pierwszej frazie) przypisana zostaje tonika, taktom 5 i 6 - subdominanta, w taktach 7-8 następuje powrót do toniki, natomiast ostatnia fraza, a więc konkluzja (takty 9-12) to kolejno dominanta, subdominanta, tonika oraz, $\mathrm{w}$ takcie dwunastym, tonika lub dominanta ${ }^{25}$. Cały schemat w bardziej czytelny sposób przedstawiony został w przykładzie 2.

\begin{tabular}{|l|l|l|l|l|}
\hline $\begin{array}{l}\text { fraza 1. } \\
\text { zawołanie }\end{array}$ & $\begin{array}{l}\text { takt 1 } \\
\text { tonika } \\
\text { np. A }\end{array}$ & $\begin{array}{l}\text { takt 2 } \\
\text { tonika } \\
\text { np. A }\end{array}$ & $\begin{array}{l}\text { takt 3 } \\
\text { tonika } \\
\text { np. A }\end{array}$ & $\begin{array}{l}\text { takt 4 } \\
\text { tonika } \\
\text { np. A }\end{array}$ \\
\hline $\begin{array}{l}\text { fraza 2. } \\
\text { zawołanie } \\
\text { powtórne }\end{array}$ & $\begin{array}{l}\text { takt 5 } \\
\text { subdomi- } \\
\text { nanta } \\
\text { np. D }\end{array}$ & $\begin{array}{l}\text { takt 6 } \\
\text { subdomi- } \\
\text { nanta } \\
\text { np. D }\end{array}$ & $\begin{array}{l}\text { takt 7 } \\
\text { tonika } \\
\text { np. A }\end{array}$ & $\begin{array}{l}\text { takt 8 } \\
\text { tonika } \\
\text { np. A }\end{array}$ \\
\hline $\begin{array}{l}\text { fraza 3. } \\
\text { konkluzja }\end{array}$ & $\begin{array}{l}\text { takt 9 } \\
\text { dominanta } \\
\text { np. E }\end{array}$ & $\begin{array}{l}\text { takt 10 } \\
\text { subdomi- } \\
\text { nanta } \\
\text { np. D }\end{array}$ & $\begin{array}{l}\text { takt 11 } \\
\text { tonika } \\
\text { np. A }\end{array}$ & $\begin{array}{l}\text { takt 12 } \\
\text { dominanta/ } \\
\text { tonika } \\
\text { np. E/A }\end{array}$ \\
\hline
\end{tabular}

Przykład 2. Schemat harmoniczny 12-taktowej formy bluesa.

Z tradycją bluesową związany jest także charakterystyczny kontur linii melodycznej, opisany dobrze przez Moore'a. Mowa o opadającej melodii, powtarzanej (czasem z drobną ornamentacją) w każdej z trzech kolejnych fraz ${ }^{26}$. Dobrym przykładem, który przywołuję za Mooreem, jest Somebo-

\footnotetext{
24 Tamże, s. 51.

25 D. Hatch, S. Millward, From Blues to Rock. An Analytic History of Pop Music, Worcester 1987, s. 184.

26 A.F. Moore, dz. cyt., s. 50.
} 
dy in My Home Howlin' Wolfa (przykład 3.), ale podobnego schematu doszukiwać się można w szeregu innych utworów bluesowych.

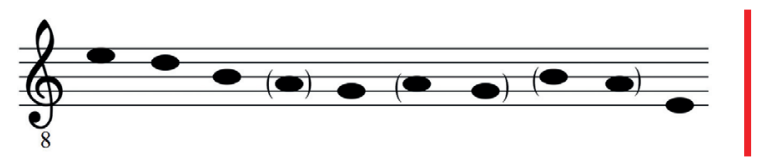

Przykład 3. Opadająca linia melodyczna w Somebody in My Home ${ }^{27}$ Howlin' Wolfa. Nuty bez nawiasów są wspólne dla wszystkich ekspozycji melodii, podczas gdy nuty ujęte w nawiasy pojawiają się w kolejnych wersach w różnych kombinacjach.

W miarę rozwoju stylistyki bluesowej doszło do pojawienia się jeszcze jednego, bardzo popularnego pomysłu melodycznego, związanego z użyciem pianina - mowa o boogie (ew. boogie-woogie). Schemat ten opiera się na szybkich przebiegach (najczęściej ósemkowych - tzw. eight to the bar, tj. „osiem w takcie”), zwykle stanowiących podstawę basową utworu, a więc granych przez pianistę lewą ręką, tworzących linię melodyczną o charakterystycznym, falistym konturze, często z użyciem synkopowanego rytmu ${ }^{28}$. Początkowo boogie było nierozerwalnie związane $\mathrm{z}$ bluesem i wpisane $\mathrm{w}$ znany nam już 12-taktowy schemat bluesowy (przykład 4.), z czasem jednak owa figura melodyczna przeniknęła do innych stylistyk, np. do rockabilly czy rock and rolla, stając się czymś na wzór „basu Albertiego muzyki popularnej”.

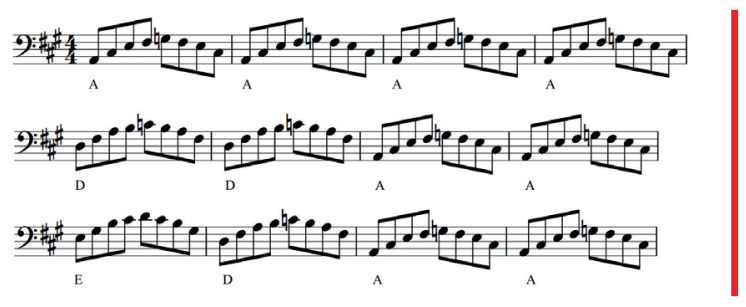

Przykład 4. Jedna z typowych melodii boogie, wpisana w schemat 12-taktowego bluesa. Przykład ma charakter uproszczony - w praktyce wykonawczej zwykle stosuje się ornamentację, synkopowany rytm czy triole.

27 Howlin' Wolf, Somebody in My Home, muz. i tekst Ch.A. Burnett, Chess Records 1959. 28 D. Hatch, S. Millward, dz. cyt., s. 181-186. 
Co zrobić jednak z utworami, których autorzy nie korzystają z gotowych schematów, takich jak 12-taktowy blues? Czy ich procesem twórczym rządzą jakieś odgórne zasady? Czy harmonikę muzyki rockowej można w jakiś sposób usystematyzować? Z odpowiedzią na te pytania przychodzi trzech rozwijających wspólną myśl badaczy: Arnold Schoenberg, Richard Middleton oraz przywoływany już Allan F. Moore. Pierwszy z nich w swoich badaniach nad teorią kompozycji przedstawił koncepcję, wedle której utwory muzyczne (Schoenberg odnosił się do muzyki poważnej) zbudowane są z okresów (periods), składających się z kolei z dwóch zdań muzycznych (phrases). Owe zdania (zwane zwykle poprzednikiem i następnikiem) mogą pozostawać w różnorakiej zależności: otwarte/zamknięte (open/closed), otwarte/ otwarte (open/open) oraz zamknięte/zamknięte (closed/closed), gdzie za zdanie zamknięte uważa się takie, które kończy się powrotem do toniki ${ }^{29}$. Middleton zaadaptował ów system, zauważając, że pośród owych trzech sposobów kształtowania okresu muzycznego, w muzyce popularnej najczęściej używana jest formuła otwarte/zamknięte (open/ closed). Ponadto wyróżnił jeszcze jeden sposób komponowania utworu popularnego, który nazwał open-ended repetitive pattern, czyli powtarzalnym schematem o otwartym zakończeniu ${ }^{30}$.

Allan F. Moore rozwinął przemyślenia Middletona, zwracając przy okazji uwagę na szereg konkretnych przykładów stosowania danego schematu $\mathrm{w}$ muzyce rockowej, dlatego też właśnie jego obserwacje będą dla nas w tym momencie najbardziej przydatne. Za najprostszy rodzaj kompozycji uważa Moore open-ended repetitive pattern. Utwory tego typu opierają się na powtarzanym wielokrotnie schemacie akordowym - przykładem takiego rozwiązania może być Hey Joe ${ }^{31}$ Jimiego Hendriksa, bazujące na sekwencji C-G-D-A-E ${ }^{32}$.

29 A. Schoenberg, Fundamentals of Musical Composition, London-Boston 1970, s. 1-19.

30 R. Middleton, Studying Popular Music, Philadelphia 199o, s. 238.

31 The Jimi Hendrix Experience, Hey Joe, muz. i tekst B. Roberts, Polydor 1966.

32 A.F. Moore, dz. cyt., s. 55-56. 


\begin{tabular}{|l|l|l|}
\hline & $\begin{array}{l}\text { Open-ended repetitive } \\
\text { pattern }\end{array}$ & Open/closed principle \\
\hline $\begin{array}{l}\text { Charakterystyka war- } \\
\text { stwy harmonicznej }\end{array}$ & $\begin{array}{l}\text { utwór oparty w całości } \\
\text { lub w przeważającej } \\
\text { części na powtarzanych } \\
\text { wielokrotnie tych } \\
\text { samych sekwencjach } \\
\text { akordów }\end{array}$ & $\begin{array}{l}\text { szereg okresów } \\
\text { muzycznych dzielących } \\
\text { się na dwa zdania, } \\
\text { spośród których } \\
\text { pierwsze jest „,otwarte” } \\
\text { (kończy się na stopniu } \\
\text { innym niż tonika, często } \\
\text { na dominancie), a dru- } \\
\text { gie „zamknięte” (pow- } \\
\text { raca do toniki) }\end{array}$ \\
\hline $\begin{array}{l}\text { Relacja względem } \\
\text { budowy formalnej } \\
\text { utworu }\end{array}$ & $\begin{array}{l}\text { najpierw powstaje sche- } \\
\text { mat akordowy (ew. kilka } \\
\text { schematów), a na ich } \\
\text { podstawie kształtowana } \\
\text { jest ogólna budowa for- } \\
\text { malna utworu (zwrotki, } \\
\text { refreny itd.) }\end{array}$ & $\begin{array}{l}\text { kompozycji jest już } \\
\text { zaplanowana, a sek- } \\
\text { wencje akordów mają } \\
\text { za zadanie ją wypełnić, } \\
\text { przez co w efekcie są } \\
\text { mniej schematyczne } \\
\text { i mniej powtarzalne }\end{array}$ \\
\hline $\begin{array}{l}\text { Pochodzenie } \\
\text { schematu }\end{array}$ & $\begin{array}{l}\text { popularne utwory } \\
\text { taneczne }\end{array}$ & $\begin{array}{l}\text { utwory z kręgu tzw. } \\
\text { muzyki poważnej }\end{array}$ \\
\hline
\end{tabular}

Przykład 5. Dwa podstawowe schematy konstrukcji harmonicznej w muzyce rockowej wg Middletona i Moore'a.

Z kolei kompozycje oparte na Schoenbergowskich zdaniach w układzie otwarte/zamknięte (open/closed), są uważane za bardziej wymagające dla kompozytora. Powstają one zazwyczaj wtedy, gdy nadrzędna jest forma utworu, a schemat akordowy ma za zadanie daną formę wypełnić (w przypadku open-ended repetitive patterns zależność ta jest odwrócona - najpierw tworzony jest powtarzalny pochód akordowy, a dopiero później na jego podstawie kształtuje się zwrotki czy refreny). Fakt, iż zwykle okresy składają się ze zdań otwartych i następujących po nich zdań zamkniętych spowodowany jest po pierwsze tym, że w ten sposób harmonia - a, co za tym idzie, także melodia - zostaje zauważalnie urozmaicona, choć bez jednoczesnej utraty poczucia ciągłości, a po drugie, wyraźnie zaznaczone zostają kadencje (np. na końcach wersów czy zwrotek). Cech takich brak utworom, w których zdania złożone są na zasadzie otwarte/otwarte (gdzie tonika występuje tylko na początku zdań), a także tym opartym na zależności zamknię- 
te/zamknięte (każde zdanie kończy się powrotem do toniki) ${ }^{33}$. Przywoływanym przez Moore’a przykładem kompozycji opartej na zależności zamknięte/zamknięte jest Proud Mary ${ }^{34}$ zespołu Creedence Clearwater Revival, gdzie tak naprawdę przez zdecydowaną większość czasu rozbrzmiewa tonika (akord D), przez co brak całości charakteru rozwojowego. Proste porównanie najpopularniejszych schematów kompozycyjnych przedstawiono w przykładzie 5 .

Przejdźmy teraz od teoretycznych rozważań do przedstawienia praktycznych rozwiązań i zastanówmy się, w jaki sposób wykonawcy konstruują harmonię i melodię konkretnych utworów. Ilość możliwych kombinacji jest ogromna, Moore wskazuje jednak na fakt, iż niektóre następstwa akordowe są częstsze od innych. Dysponujemy ograniczoną ilością ruchów ${ }^{35}$ harmonicznych (w górę lub w dół): o sekundę, tercję lub kwartę 36 ; możemy też pozostać na tym samym stopniu skali. Możliwość ostatnia sama w sobie wiąże się z monotonią, dlatego też długie pozostawanie na tym samym stopniu, jeśli jest wykorzystywane, to najczęściej jako podstawa dla wirtuozowskiego instrumentalnego solo (patrz: akord e-moll w Riders on the Storm ${ }^{37}$ grupy The Doors). Zmiany sekundowe występują często w połączeniu z innymi, ale dłuższe sekwencje samych sekundowych kroków to już rzadkość (występująca np. w muzyce flamenco). Podobnie jest $\mathrm{z}$ „ruchami” tercjowymi, choć czasem spotykamy się np. z szeregiem opadających tercji (patrz: Stand By $M e^{38}$ Bena E. Kinga $\mathrm{z}$ sekwencją A-fis-D, po której jednak następuje ruch sekundowy w górę do E). Zdecydowanie najczęściej stosowane są skoki o kwartę (co zwykle wiąże się z funkcją subdominantową lub dominantową), przy czym je także zwykle łączy się z innymi ruchami (jednym z wyjątków jest np. przywoływane po raz kolejny Hey Joe,

33 Tamże, s. 58-59.

34 Creedence Clearwater Revival, Proud Mary, muz. i tekst J. Fogerty, Fantasy 1969.

35 Mówienie o „ruchu” w harmonii, a zwłaszcza o „ruchu akordów” wiąże się $\mathrm{z}$ pewnym brakiem precyzji. Tak jednak prezentuje kwestię harmonii Moore (stepwise moves, move by the interval of a third), a ponadto wydaje się, że powyższe - uproszczone i usystematyzowane - przedstawienie tematu pozwala na uniknięcie jakichkolwiek nieporozumień.

36 Każda kolejna możliwość jest de facto powtórzeniem wcześniejszego wariantu (ruch o kwintę w górę jest jednocześnie ruchem o kwartę w dół, ruch o sekstę w górę jest tożsamy z ruchem o tercję w dół itd.).

37 The Doors, Riders on the Storm, muz. i tekst J. Morrison/R. Krieger/ R. Manzarek/J. Densmore, Elektra 1971.

38 Ben E. King, Stand by Me, muz. i tekst B.E. King/J. Leiber/M. Stoller, Atco 1961. 
oparte na opadających kwartach C-G-D-A-E, a więc w gruncie rzeczy na wycinku koła kwintowego) ${ }^{39}$.

Warto pamiętać, iż utwory bluesowe, folkowe czy rockowe zwykle są komponowane $\mathrm{z}$ myślą o konkretnym instrumencie. Jak już zauważyłem, rzadkością w muzyce rockowej jest tworzenie piosenki „na sucho", poprzez rozpisanie partytury. Niemal zawsze konkretne kompozycje powstają przy udziale gitary czy fortepianu, co może mieć wyraźny wpływ na ich konstrukcję melodyczno-harmoniczną. I tak na przykład, jak słusznie zauważa Moore, jedynymi trójdźwiękami durowymi, które można zagrać w pozycji otwartej (tj. bez stosowania akordów barowych i bez uciekania się do pomocy kapodastra) na standardowo nastrojonej gitarze są: C, D, E, G i A ${ }^{40}$. Wnioski Moore’a poszerzyć można o fakt, iż niektóre połączenia akordów są, ze względu na ułożenie palców na gryfie, bardziej naturalne od innych (np. przejście z a-moll do C-dur wymaga przestawienia tylko jednego z palców). Stąd też nie powinno nas dziwić, że konkretne pochody akordów występują w muzyce rockowej dużo częściej niż np. w muzyce klasycznej, podczas gdy inne, uważane w „epoce Mozarta” za typowe, należą w rocku do rzadkości. Ma to też wpływ na różnice pomiędzy konkretnymi kompozytorami z kręgu samej muzyki popularnej - podczas gdy John Lennon zwykł komponować w oparciu o gitarę, Paul McCartney dość wcześnie zaczął korzystać też z pomocy fortepianu, co jest jedną z przyczyn wyraźnych różnic w idiomie kompozytorskim obu muzyków.

Bez względu jednak na to, na jakie akordy ostatecznie decydują się wykonawcy, ich rozmieszczenie w poszczególnych taktach da się $\mathrm{w}$ większości utworów rockowych opisać prostym schematem. Konkretne myśli melodyczno-harmoniczne (a więc zdania) trwają zwykle 4 takty, nieco rzadziej 2 lub 8 taktów - zauważalna jest w każdym razie parzystość. Wyraźna jest ona także w tworzeniu sekwencji akordowych - zwykle składają się one z dwóch lub czterech akordów, a jeśli dany twórca decyduje się na sekwencję trzyakordową, to prawie na pewno jedno współbrzmienie trwać będzie tyle, co dwa pozostałe razem wzięte ( $\mathrm{w}$ wyraźny sposób widać to $\mathrm{w}$ typowych utworach punkrockowych, np. w Blitzkrieg Bop ${ }^{41}$ zespołu Ramones,

39 A.F. Moore, dz. cyt., s. 56-57.

40 Tamże, s. 59-6o.

41 Ramones, Blitzkrieg Bop, muz. i tekst T. Ramone/D.D. Ramone, Sire/ABC 1976. 
gdzie cały pierwszy takt zajmuje akord A, natomiast w takcie drugim pojawiają się dwa trwające krócej akordy, kolejno D i E, po czym cały ten schemat zostaje kilkukrotnie powtórzony) ${ }^{42}$.

Istnieje szereg utartych pomysłów harmonicznych - od najprostszych, opartych na dwóch akordach (jak np. w Shout ${ }^{43}$ zespołu The Isley Brothers, opierającym się na F-dur i d-moll), przez trzyakordowe (zwykle wykorzystujące tonikę, subdominantę i dominantę, jak u wspomnianych przed chwilą Ramones), po nieco bardziej złożone (jak chociażby popularny w latach 50. schemat I-vi-IV-V, czyli $\mathrm{T}^{-} \mathrm{T}_{\mathrm{VI}} \mathrm{S}-\mathrm{D}$, pojawiający się m.in. w przywoływanym już Stand By Me Kinga i niejako sparodiowany później przed Beatlesów w końcowej części Happiness Is a Warm Gun ${ }^{44}$ ).

$\mathrm{Na}$ koniec chciałbym powrócić jeszcze raz do kwestii melodyki. Zjawiskiem bardzo istotnym dla całej muzyki popularnej, a zwłaszcza dla nurtów rockowych jest riff. Termin ten określa prostą, krótką myśl muzyczną, powtarzaną na przestrzeni utworu. Zwykle wykonanie riffu powierza się gitarze prowadzącej (o czym więcej w ostatniej części artykułu), choć oczywiście znane są też przykłady wykonywania riffów przez inne instrumenty: fortepian (Hey Bulldog ${ }^{45}$ Beatlesów) czy np. saksofon (21st Century Schizoid Man ${ }^{46}$ zespołu King Crimson). Riff ma w muzyce popularnej status podobny do tematu w muzyce poważnej - oryginalny, ale jednocześnie chwytliwy pomysł melodyczny często stanowi dla słuchaczy o jakości danego utworu. Riff może przybierać formę ostinatową (a więc powtarzaną przez cały utwór lub jego znaczącą część, czasem w progresji, jak w kompozycji Moby Dick ${ }^{47}$ grupy Led Zeppelin), albo też występować pojedynczo, ale regularnie (np. na końcu każdej frazy w bluesie, jak w Hoochie Coochie Man ${ }^{48}$ Muddy'ego Watersa) ${ }^{49}$.

42 A.F. Moore, dz. cyt., s. 55.

43 The Isley Brothers, Shout, muz. i tekst O. Isley/R. Isley/R. Isley, RCA 1959.

44 The Beatles, Happiness Is a Warm Gun, muz. i tekst J. Lennon/P. McCartney, Apple 1968.

45 The Beatles, Hey Bulldog, muz. i tekst J. Lennon/P. McCartney, Apple 1969.

46 King Crimson, 21st Century Schizoid Man, muz. i tekst P. Sinfield, Atlantic Records 1969.

47 Led Zeppelin, Moby Dick, muz. J. Bonham/J.P. Jones/J. Page, Atlantic 1969.

48 Muddy Waters, Hoochie Coochie Man, muz. i tekst W. Dixon, Chess Records 1954.

49 W. Siwak, dz. cyt., s. 13-14; A.F. Moore, dz. cyt., s. 225. 
Nie istnieje żaden „przepis na riff”, ale wskazać można na pewne często spotykane skale czy schematy prowadzenia melodii (dotyczy to zresztą nie tylko riffu, ale i np. rozbudowanych instrumentalnych partii solowych). Spośród tych pierwszych ważne miejsce należy się tzw. skali bluesowej ${ }^{50}$, która jest de facto minorową skalą pentatoniczną poszerzoną o dodatkowy dźwięk zwany blue note. O ile blue notes mogą przyjmować różne formy (np. zmiany na poziomie mikrotonalnym), o tyle w tym wypadku mamy po prostu do czynienia $\mathrm{z}$ dodaniem dźwięku na podwyższonym czwartym stopniu skali; przykładowa skala bluesowa może więc wyglądać tak: $a-c-d$-dis-e-g (gdzie blue note to dis). Co się zaś tyczy konkretnych schematów prowadzenia melodii, to - bez uciekania się do tworzenia rozbudowanej listy takowych - podkreślić można częste korzystanie ze środków takich jak: repetycje, progresje oraz ruch po rozłożonych dźwiękach akordu.

\section{Rytmika}

Na podstawie naszych dotychczasowych przemyśleń można łatwo zauważyć, że w konstrukcji całego utworu rockowego (i w muzyce popularnej w ogóle) bardzo ważny jest rytm. To w oparciu o niego realizuje się myśli melodyczno-harmoniczne, to on kształtuje ramy budowy formalnej, to wreszcie on pomaga $\mathrm{w}$,odnalezieniu się" w przebiegu kompozycji - zarówno wykonawcom, jak i słuchaczom (zwłaszcza podczas rozbudowanych improwizacji) ${ }^{51}$.

Przy analizie rytmiki utworów rockowych, po raz kolejny pojawia się problem notacji muzycznej. Jako że muzyka rockowa jest zazwyczaj nienotowana, zapis utworów rockowych, w tym także np. podział na takty, pozostawia pewną dowolność. W takiej sytuacji pomocne okazuje się aprioryczne przyjęcie jakiegoś schematu ${ }^{52}$. Ów schemat - zwany przez Moore'a standard rock beat, a przez Covacha typical drumbeat - związany jest w bezpośredni sposób ze składem zestawu perkusyjnego. Przynajmniej dla części czytelników będą to kwestie oczywiste, muszę jednak wyjść od nich, aby później wyciągnąć bar-

50 Czasem wyróżnia się kilka różnych skal bluesowych, przy czym ta wyżej przedstawiona pozostaje najpopularniejsza.

51 W. Siwak, dz. cyt., s. 14.

52 A.F. Moore, dz. cyt., s. 42. 
dziej szczegółowe wnioski. Spójrzmy więc na uproszczony schemat zestawu perkusyjnego: bęben basowy (in. bęben wielki; uruchamiany stopą, za pomocą specjalnego mechanizmu; ang. bass drum), werbel (ang. snare) oraz hi-hat (podwójny talerz perkusyjny, uderzany zarówno pałeczką, jak też, podobnie jak bęben wielki, za pomocą stopy). Oprócz tego często używane są: tom-tom (rodzaj bębna), inne talerze (cymbals), np. ride czy crash, a okazjonalnie także inne instrumenty perkusyjne (gong czy „krowi dzwonek” - cowbell) ${ }^{53}$.

Ów „standardowy rytm rockowy” (tak naprawdę charakterystyczny nie tylko dla rocka) opiera się na podziale każdego taktu na 4 części (dla metrum 4/4), gdzie bęben basowy akcentuje mocne części taktu, tj. 1. i 3. uderzenie, werbel części słabe. tj. uderzenia 3. i 4., a talerze wypełniają rytm krótszymi uderzeniami, zwykle ósemkowymi. Schemat ten przedstawiony został w przykładzie 6 . Rzeczą charakterystyczną jest także zagęszczenie faktury rytmicznej (zwykle za pomocą werbla czy tom-tomów) podczas momentów istotnych z punktu widzenia budowy formalnej utworu, a więc np. przy przejściu od zwrotki do refrenu ${ }^{54}$.

\begin{tabular}{|l|l|l|l|l|l|l|l|l|l|}
\hline & 1 & $\mathrm{i}$ & 2 & $\mathrm{i}$ & 3 & $\mathrm{i}$ & 4 & $\mathrm{i}$ & $\ldots$ \\
\hline Bęben basowy & $\mathrm{x}$ & & & & $\mathrm{x}$ & & & & \\
\hline Werbel & & & $\mathrm{x}$ & & & & $\mathrm{x}$ & & \\
\hline Hi-hat & $\mathrm{x}$ & $\mathrm{x}$ & $\mathrm{x}$ & $\mathrm{x}$ & $\mathrm{x}$ & $\mathrm{x}$ & $\mathrm{x}$ & $\mathrm{x}$ & \\
\hline
\end{tabular}

Przykład 6. Schemat realizacji „standardowego rytmu rockowego" przez podstawowy zestaw perkusyjny (oparty na systemie TUBS55).

Za przedstawionym wyżej porządkiem podąża, jak zauważyłem na wstępie, struktura całego utworu. Bardzo dobrze widać to, gdy spojrzymy na stosowane sekwencje harmoniczne. Otóż zmiany akordów są związane bezpośrednio z „biciem” narzucanym przez perkusję, odbywa-

53 J. Covach, dz. cyt., s. 222.

54 A.F. Moore, dz. cyt. 38; J. Covach, dz. cyt., s. 222-223.

55 „Time Unit Box System” - prosty system służący do zapisu rytmu w muzyce, skodyfikowany przez Philipa Harlanda oraz Jamesa Koettinga na potrzeby etnomuzykologii, ale wykorzystywany w różnych wersjach i dla różnych potrzeb, w tym m.in. w badaniach nad muzyką popularną (zwłaszcza przez Covacha). 
jąc się najczęściej na początku taktu („na raz”), albo ewentualnie w jego połowie („na trzy”) $)^{56}$.

Błędem byłoby jednak twierdzenie, że muzyka popularna kurczowo trzyma się mocnych części taktu. Szereg wykonawców - niezależnie od tego czy są świadomi swoich „bluesowych korzeni”, czy nie bardzo często stosuje synkopy, a więc przesuwa akcent na słabe części taktu (off-beat) ${ }^{57}$. Istotna staje się zależność występująca między rytmem narzucanym przez perkusję, a pierwszoplanową melodią, czy to wygrywaną na gitarze, czy też śpiewaną przez wokalistę. Umiejętne oscylowanie wokół podstawowego rytmu bez jednoczesnego jego "gubienia" jest ćwiczone przez wykonawców i chwalone przez słuchaczy, wiążąc się z nie do końca uchwytnym terminem feeling ${ }^{58}$.

W związku z dominującą rolą metrum 4/4 duże znaczenie dla badaczy muzyki popularnej zyskują wszelkie utwory, które wyraźnie z owego metrum rezygnują. W pracy badawczej szczególnie ważne jest zastanowienie się, czym owa rezygnacja jest spowodowana i jaką jakość ze sobą niesie. Dobrym przykładem na zakończenie naszych rozważań o rytmice może być piosenka Being for the Benefit of Mr. Kite! ${ }^{59}$ zespołu The Beatles, gdzie po słowach ,and of course Henry the Horse dances the waltz” („a koń Henryk oczywiście tańczy walca”) metrum zmienia się, jak można się domyślić, na 3/4.

\section{Instrumentacja}

Brzmienie prezentowane przez wykonawców muzyki rockowej, zwłaszcza w szczególnie interesującym nas okresie lat 50.-70., było w dużej mierze determinowane przez ustandaryzowany skład instrumentalny. Wywodził się on w prostej linii od miejskiego, chicagowskiego bluesa. Podczas tzw. Wielkiej Migracji (zwłaszcza w latach 20.-40. XX w.) setki tysięcy Murzynów ${ }^{60}$ trafiły z wiejskich obszarów Południa Stanów Zjed-

56 A.F. Moore, dz. cyt., s. 42.

57 D. Hatch, S. Millward, dz. cyt., s. 184-185.

58 A.F. Moore, dz. cyt., s. 43-44.

59 The Beatles, Being for the Benefit of Mr. Kite!, muz. i tekst J. Lennon/P. McCartney, Parlophone 1967.

60 Dla potrzeb poprawności politycznej wyjaśnijmy, iż słowo „Afroamerykanin” w tym kontekście stanowiłoby niepotrzebny anachronizm. Nie należy też przesadnie obawiać się słowa „Murzyn” jako rzekomo obraźliwego, o czym szerzej w tek- 
noczonych do uprzemysłowionych miast Północy, przywożąc ze sobą swoją kulturę, w tym również bluesa, który w środowisku miejskim uległ licznym przemianom. Przekształcone zostało także instrumentarium gitary akustyczne zaczęto zamieniać na elektryczne, by dało się je słyszeć w coraz bardziej zatłoczonych klubach i by nie były zagłuszane dźwiękami coraz liczniejszej grupy innych instrumentów. Sekcję rytmiczną stanowiły perkusja oraz kontrabas (później zamieniany na gitarę basową), czasem wtórował im fortepian, a sekcja dęta, charakterystyczna dla bigbandowej muzyki jazzowej, bywała nierzadko niwelowana do pojedynczej (choć wzmacnianej za pomocą mikrofonu) harmonijki ustnej61.

Wkrótce schemat ten został spopularyzowany przez muzykę rockandrollową, aż wreszcie trafił za Ocean Atlantycki - do Wielkiej Brytanii, gdzie w latach 6o. powstające masowo młodzieżowe zespoły (w tym późniejsze sławy pokroju Beatlesów), po krótkotrwałym epizodzie z muzyką skiffle ${ }^{62}$, pomogły ukształtować znane nam do dziś, klasyczne brzmienie rockowe oparte o: zestaw perkusyjny, gitarę basową, gitarę rytmiczną, gitarę prowadzącą oraz głos wokalny ${ }^{63}$.

Rola zestawu perkusyjnego została już przeze mnie w dużej mierze omówiona. W tym momencie warto jednak dodać, że powtarzalność obserwowana w przedstawionym „standardowym rytmie rockowym” pełni dwojaką funkcję: do takiej muzyki łatwiej tańczyć, a ponadto powtarzalność $\mathrm{w}$ warstwie rytmicznej pozwala na łatwiejsze uchwycenie zmian harmonicznych czy melodycznych ${ }^{64}$. Urozmaicenia są zwykle ograniczone do różnic występujących w „biciu” w poszczególnych częściach utworu (np. zwrotce i refrenie), a także do przejść między nimi. Osobną wartość stanowią, wyrosłe ze stylistyki jazzowej, solowe improwizacje perkusyjne, charakterystyczne zwłaszcza dla wykonań koncer-

ście: M. Łaziński, Murzyn zrobił swoje. Czy Murzyn może odejść? Historia i przyszłość słowa „Murzyn” w polszczyźnie, „Poradnik Językowy” 2007, nr 4, s. 47-56.

61 N. Williamson, The Rough Guide to the Blues, London 2007, s. 44-45, 49; G. Piotrowski, dz. cyt., s. 58.

62 Muzyka o korzeniach bluesowych i folkowych, charakteryzująca się korzystaniem z prostych, często improwizowanych instrumentów, takich jak np. tara do prania. Popularność muzyki skiffle wśród młodych zespołów brytyjskich brała się w dużej mierze z niemożności łatwego zdobycia prawdziwych instrumentów muzycznych.

63 A.F. Moore, dz. cyt., s. 35-36.

64 Tamże, s. 37. 
towych (zasłynęli nimi m.in. Ginger Baker z zespołu Cream oraz John Bonham z Led Zeppelin $\left.{ }^{65}\right)$.

Wyjątkowo zróżnicowana, a często niedoceniana jest rola, jaką powierza się gitarzyście basowemu. Po pierwsze, jego zadaniem jest wspieranie perkusisty w podtrzymywaniu rytmu - w tym celu akcentuje on mocne części taktu, w podobny sposób jak czyni to bęben wielki. Zazwyczaj wykorzystywany jest podstawowy dźwięk granego akurat akordu (np. $c$ dla akordu C-dur), przez co gitara basowa pełni też funkcję podstawy harmonicznej. Trzecią rolą, jaką powierza się basiście, jest prowadzenie własnej linii melodycznej, często w postaci tzw. walking bass line (kroczącej linii basu). To, na ile owa melodia będzie niezależna od pozostałych instrumentów, świadczy o umiejętnościach wykonawcy, choć przez wielu słuchaczy i tak pozostaje ona niezauważona. Wyjątkami pozostają kompozycje, w których melodia gitary basowej jest szczególnie akcentowana, jak w My Generation ${ }^{66}$ zespołu The Who (gdzie w konkretnych miejscach pozostałe instrumenty cichną, by zaprezentować umiejętności Johna Entwistle’a), albo Think for Yourself ${ }^{67}$ Beatlesów (gdzie Paul McCartney zastosował gitarowy efekt fuzz, przez co jego gitara basowa jest bardziej słyszalna) ${ }^{68}$.

Gitara rytmiczna, jak sama nazwa wskazuje, jest kolejnym instrumentem należącym do sekcji rytmicznej. O ile jednak gitara basowa niemal zawsze akcentuje mocne części taktu, o tyle gitarze rytmicznej często zdarza się pozostawać $\mathrm{z}$ nią $\mathrm{w}$ dialogu, akcentując części słabe (podobnie jak czyni to werbel; szczególnie widoczne jest to $\mathrm{w}$ takich gatunkach jak ska, rocksteady i reggae); możliwe jest także (np. w muzyce metalowej czy w punk rocku) stosowanie uderzeń ósemkowych (podążających niejako za hi-hatem) lub jeszcze szybszych. Ponadto gitarzysta rytmiczny, grając akordy, zapewnia utworowi wypełnienie harmoniczne, jego partia znajduje się więc niejako pomiędzy podstawą basową a dźwiękami wysokimi ${ }^{69}$.

Owe wysokie partie realizowane są $\mathrm{w}$ dużej mierze przez gitarę prowadzącą. Najczęściej odbywa się to przy użyciu opisanego przez nas na wcześniejszych stronach riffu, choć możliwe jest też np. zastosowanie

65 Por.: Cream, Toad, muz. G. Baker, Polydor 1966; Led Zeppelin, Moby Dick, dz. cyt.

66 The Who, My Generation, muz. i tekst P. Townshend, Brunswick 1965.

67 The Beatles, Think for Yourself, muz. i tekst G. Harrison, Parlophone 1965.

68 J. Covach, dz. cyt., s. 223-224; A.F. Moore, dz. cyt., s. 39.

69 J. Covach, dz. cyt., s. 224. 
akordowego arpeggio. Często do obowiązków gitarzysty prowadzącego należy także wykonywanie instrumentalnych partii solowych - zarówno wcześniej zaplanowanych, jak i improwizowanych ${ }^{70}$.

Niezwykle istotną rolę odgrywa w muzyce popularnej (poza utworami czysto instrumentalnymi) wokalista ${ }^{71}$. Musi on w tym samym czasie przekazywać słuchaczom treść tekstu, oddawać zawarte w słowach emocje, prezentować „chwytliwą” melodię, a także - o czym wspomniałem w poprzedniej części artykułu - w interesujący sposób operować rytmem. W wielu utworach bardzo istotne są harmonie wokalne, tzw. chórki (backing vocals), zwykle prezentowane przez resztę zespołu, czasem przez specjalnie do tego zatrudnionych chórzystów. $\mathrm{W}$ repertuarze niektórych zespołów (np. The Beach Boys ${ }^{72}$ ) stanowią one bodaj najistotniejszą część wykonania, będąc niejako kontynuacją stylistyki popularnych we wcześniejszych dekadach męskich i żeńskich grup wokalnych z nurtu doo-wop czy barbershop music.

Praktyką niestandardową, co nie znaczy, że rzadko spotykaną, jest stosowanie innych instrumentów niż wcześniej wymienione. Tak jak gitary pozostają spuścizną po bluesie chicagowskim, tak użycie pianina ma korzenie w muzyce nowoorleańskiej (a rozpowszechnione zostało przez muzyków rockandrollowych, takich jak Little Richard) ${ }^{73}$. Nierzadkie jest także stosowanie instrumentów dętych (których obecność można by $\mathrm{z}$ kolei wiązać m.in. z jump bluesem ${ }^{74}$ ) czy smyczkowych, zwykle w grupach (np. kwartet smyczkowy) ${ }^{75}$. Należy tu jednak wyróżnić dwie możliwe sytuacje - kiedy poszerzenie instrumentarium jest decyzją producentów muzycznych czy reżyserów dźwięku (tak jak miało to miejsce w wypadku debiutanckiego albumu grupy The Crazy World of Arthur Brown, kiedy konieczne okazało się „przykrycie” nierównej gry perkusisty ${ }^{76}$ ) lub kiedy wynika ono z w pełni świadomej de-

70 A.F. Moore, dz. cyt., s. 40-41; J. Covach, dz. cyt., s. 225.

71 Skrótowo podsumowuje różne sposoby ekspresji wokalnej w muzyce rockowej Piotrowski; por. tenże, dz. cyt., s. 59-62.

72 Por. The Beach Boys, Surfin' Safari, muz. i tekst B. Wilson/M. Love, Capitol 1962.

73 A.F. Moore, dz. cyt., s. 35-36.

74 Por. Louis Jordan \& His Tympany Five, Caldonia, muz. i tekst F. Moore, Decca 1945. Notabene, utwór uważany za jeden $\mathrm{z}$ „kamieni węgielnych” rock and rolla.

75 J. Covach, dz. cyt., s. 226.

76 R. Unterberger, Urban Spacemen and Wayfaring Strangers. Overlooked Innovators and Eccentric Visionaries of '6os Rock, San Francisco 2000, s. 44-45; por. The Crazy World of Arthur Brown, Fire, muz. i tekst A. Brown/V. Crane/M. Finesilver/P. Ker, Track 1968. 
cyzji zespołu (jak w utworze Pictures of Lily ${ }^{77}$ zespołu The Who, gdzie basista John Entwistle gra także na rogu - instrumencie, na którym ćwiczył w szkole muzycznej). Oczywiście nierzadko spotykaną sytuacją jest porozumienie pomiędzy zespołem a producentem/reżyserem. $\mathrm{Z}$ kolei wprowadzenie takiego dodatkowego instrumentu do stałego składu grupy pozostaje dość rzadkie i zwykle w interesujący sposób redefiniuje klasyczne brzmienie, czego przykładem istotna rola fletu poprzecznego w muzyce zespołu Jehtro Tull ${ }^{78}$.

Charakterystyczne dla muzyki popularnej jest także szybkie podążanie za trendami i chętne korzystanie $\mathrm{z}$ najnowszych zdobyczy techniki. Wszelkie muzyczne wynalazki dość szybko trafiały do utworów rockowych - stało się tak m.in. z thereminem (użytym chociażby w Good Vibrations $^{79}$ Beach Boysów), melotronem (Strawberry Fields Forever ${ }^{80}$ Beatlesów), organami Hammonda (Gimme Some Lovin's1 The Spencer Davis Group) czy syntezatorem Mooga (Strange Days ${ }^{82}$ The Doors). Bardzo szybko zareagowali też artyści rockowi na nowe trendy w muzyce eksperymentalnej, stosując kolaże dźwiękowe i realizując założenia tzw. muzyki konkretnej (patrz: inspirowane działalnością Karlheinza Stockhausena Revolution $9^{83}$ Beatlesów) czy adaptując do swoich potrzeb pionierskie rozwiązania muzyki elektronicznej (syntezatory programowane przez Petea Townshenda $\mathrm{z}$ The Who ${ }^{84}$ ), przez co $\mathrm{z}$ czasem muzycy zaczęli spędzać w studiu nagraniowym całe miesiące, a nie, jak w przypadku debiutanckiego długogrającego albumu Beatlesów (Please Please Me z 1963 roku), jeden dzień.

$\mathrm{W}$ ten sposób przechodzimy płynnie do ostatniego interesującego mnie zagadnienia. Wspominałem już o stosowaniu eksperymentalnych zabiegów studyjnych, a jeszcze wcześniej o odbywających się w studiu nagraniowym próbach rozszerzania instrumentarium. Tymczasem

77 The Who, Pictures of Lily, muz. i tekst P. Townshend, Track 1967.

78 Por. Jethro Tull, Living in the Past, muz. i tekst I. Anderson, Island Records 1969.

79 The Beach Boys, Good Vibrations, muz. i tekst B. Wilson/M. Love, Capitol 1966.

80 The Beatles, Strawberry Fields Forever, muz. i tekst J. Lennon/P. McCartney, Parlophone 1967.

81 The Spencer Davis Group, Gimme Some Lovin', muz. i tekst S. Windwood/S. Davis/M. Windwood, Fontana 1966.

82 The Doors, Strange Days, muz. i tekst J. Morrison/R. Manzarek/R. Krieger/J. Densmore, Elektra 1967.

83 The Beatles, Revolution 9, muz. i tekst J. Lennon/P. McCartney, Apple Records 1968.

84 Por. The Who, Baba O’Riley, muz. i tekst P. Townshend, Polydor 1971. 
prace studyjne determinują ostateczne brzmienie utworów w znacznie większym stopniu. Przypomnę raz jeszcze: w muzyce rockowej przedmiotem badań nie jest, jak w przypadku muzyki poważnej, zapis nutowy, ale konkretnie nagranie (ew. wykonanie na żywo) - czy to jeden utwór, czy cały album. I nie jest to spowodowane jedynie wspomnianymi na początku rozdziału problemami ze zdobyciem (i proweniencją) partytur z utworami popowymi. Istotne jest także - a może przede wszystkim - to, że klasyczny zapis nutowy może oddać tylko fragment brzmienia takiego utworu. O ile np. w partyturze z muzyką romantyczną informacja ,wiolonczela" jest w zdecydowanej większości wypadków wystarczająca i dla wykonawców, i dla badaczy, o tyle samo określenie "gitara elektryczna” niewiele nam mówi. Spowodowane jest to daleko posuniętymi w muzyce rockowej procesami przetwarzania dźwięku zarówno wprowadzanymi przez samych wykonawców (np. przez stosowanie efektów gitarowych czy dobór odpowiednich wzmacniaczy), jak i właśnie za sprawą pracy studyjnej ${ }^{85}$. Czasem ingerencja producentów muzycznych w nagranie jest tak istotna i tak charakterystyczna, że oni sami stają się bardziej znani od wykonawców, których muzyką się zajmują. Dobrym tego przykładem postać Phila Spectora i typowej dla produkowanych przez niego nagrań tzw. „ściany dźwięku” (Wall of Sound ${ }^{86)}$. Sposób rejestracji poszczególnych ścieżek, charakterystyka studia nagraniowego, stosowane efekty, użycie stereo (a z czasem także bardziej przestrzennych systemów) - wszystko to wpływa w istotny sposób na ostateczne brzmienie utworu, a pozostaje nieuchwytne w zapisie nutowym.

85 A.F. Moore, dz. cyt., s. 35; G. Piotrowski, dz. cyt., s. 48.

86 Sposób produkcji utworów muzycznych stosowany na szeroką skalę przez Phila Spectora w słynnym studiu nagraniowym Gold Star w Los Angeles, głównie na początku lat 6o. Spector zerwał z praktyką osobnego nagrywania poszczególnych instrumentów i takiego rozmieszczania ich na taśmie, by każdy był dobrze słyszalny. Zamiast tego nagrywał je jednocześnie, a potem miksował w taki sposób, że utwór składał się jedynie z dwóch dających się rozróżnić warstw: pierwszej, z głównym wokalem i ew. solowymi partiami instrumentalnymi, oraz drugiej, tworzącej całe tło rytmiczno-harmoniczne, z niejednokrotnie trudnymi do zidentyfikowania instrumentami - rzeczonej „ściany dźwięku”. 


\section{Podsumowanie}

Konkludując, należy stwierdzić, że muzykologa chcącego badać muzykę rockową czekają istotne trudności metodologiczne. Przede wszystkim zmienia się przedmiot badań - dominujący w tradycyjnej muzykologii zapis nutowy w wypadku rozważań nad muzyką rockową staje się nieadekwatny, m.in. dlatego, że jego proweniencja często bywa wtórna (powstaje on już po skomponowaniu i nagraniu utworu) i nie uwzględnia on stosowanych przez muzyków efektów czy zmian wprowadzanych w studiu. Po drugie, nieodpowiednia i niewystarczająca jest też funkcjonująca terminologia - zupełnie inna niż w muzyce poważnej jest np. klasyfikacja kompozycji ze względu na budowę formalną, inne są też same części składowe utworów. Po trzecie wreszcie, analiza elementów dzieła muzycznego, do której przyzwyczaiła nas muzykologia tradycyjna, w wielu wypadkach prowadzić będzie do wniosków powtarzalnych i mało istotnych - np. opis warstwy harmonicznej utworu, który w wypadku kompozycji Wagnera przerodzić się może $\mathrm{w}$ wielostronicowe analizy, w przypadku niejednego utworu popularnego skwitować można choćby stwierdzeniem „blues w A”.

Czy znaczy to, że muzykolodzy powinni porzucić rozważania nad muzyką rockową? Pytanie to ma oczywiście charakter retoryczny (zwłaszcza, że już od pewnego czasu grupa muzykologów rzeczywiście muzyką rockową się zajmuje), ale należy na nie odpowiedzieć, by podkreślić sedno sprawy. Otóż analiza warstwy muzycznej pozostaje w wypadku utworów rockowych niezwykle istotna i to właśnie muzykologia może dostarczyć najpełniejszych odpowiedzi w tym zakresie. Konieczna jest jednak zmiana podejścia i dostosowanie narzędzi badawczych do nieco odmiennych realiów. Przedmiotem badań dla zainteresowanych muzyką popularną powinno być nagranie dźwiękowe (ew. wykonanie na żywo), podczas gdy zapis nutowy stanowić może co najwyżej źródło drugorzędne. Nieodzowne jest też przyswojenie sobie odmiennej, specyficznej terminologii - zwrócenie uwagi na takie elementy muzyki popularnej jak bridge, 12-taktowy schemat bluesowy, boogie, riff czy feeling. Nie może też badacz omijać zjawisk, które w przypadku muzyki poważnej zwykle nie wy- 
stępują ${ }^{87}$, a dla muzyki popularnej stanowią praktykę powszechną, a więc zwłaszcza sposobów przetwarzania dźwięku przez samych wykonawców (np. za pomocą efektów gitarowych), jak i przez pracowników studiów nagraniowych. Z drugiej strony, omówienie niektórych aspektów utworu, jak np. jego rytmiki, musi zostać w wielu wypadkach znacząco ograniczone, choćby dlatego, że podziału na takty w sytuacji braku zapisu nutowego dokonuje, zwykle w niejako arbitralny sposób, sam badacz. Ponadto wyliczenie dziesięciu utworów, spośród których każdy utrzymany jest w metrum 4/4, nie będzie zbyt wartościowe - istotne staną się one dopiero wtedy, gdy zestawimy je z utworem jedenastym, który łamie tę regułę, po czym spróbujemy dowieść czym podyktowana jest taka zmiana, z jakiej tradycji się wywodzi, a jakich standardów jest zaprzeczeniem itp. Podobnie będzie w wielu przypadkach $\mathrm{z}$ warstwą harmoniczną czy melodyczną.

Wiąże się to $\mathrm{z}$ istotą omawianej muzyki - jak bowiem zauważyłem wcześniej, historia muzyki rockowej to historia schematów oraz prób ich łamania. Dlatego tak bardzo istotne jest, by osoby badające ten obszar muzyki znały nie tylko interesujący ich w danym momencie utwór czy album muzyczny, ale także (a może przede wszystkim) węższy i szerszy kontekst. Konstatacja ta, istotna też w wypadku muzyki poważnej (czy ludowej), zyskuje w wypadku muzyki popularnej znaczenie szczególne. Wydaje się, że zauważyli to przedstawiciele popular music studies na Zachodzie, czego przykładem może być np. artykuł znanego nam już Johna Covacha, w którym śledzi on budowę formalną utworów zespołu The Beatles. Covach zauważa między innymi, że popularna na samym początku działalności liverpoolskiej grupy forma AABA zaczęła, w miarę nagrywania kolejnych albumów, ustępować formie zwrotkowo-refrenowej, a z czasem doszło też do wykształcenia się oryginalnego schematu, który Covach określa jako Beatles' contrasting verse-chorus form (Beatlesowska kontrastująca forma zwrotkowo-refrenowa), gdzie utwór nie tylko jest podzielony na różniące się tekstowo i muzycznie zwrotki oraz refreny, ale także występują w jego przeciągu dwie odmienne wersje refrenu. Na pod-

87 Współczesna muzyka poważna, czerpiąca zresztą niejednokrotnie ze zdobyczy muzyki popularnej, wprowadziła oczywiście w tym względzie daleko idące zmiany i tak np. użycie elektrycznych gitar czy systemów przetwarzania i wzmacniania dźwięku w muzyce Louisa Andriessena nie jest już dla nas niczym dziwnym. 
stawie dokładniejszej analizy wybranych kompozycji badacz dochodzi do wniosku, że budowa formalna jest jednym $\mathrm{z}$ wielu aspektów, w których utwory Beatlesów nie tylko rozwijały się, ale także wytyczały nowe, uprzednio mało znane ścieżki w muzyce popularnej ${ }^{88}$. Spogląda więc Covach na twórczość Beatlesów z perspektywy muzykologa, ale korzystając z nowej, odpowiedniej terminologii, kładąc nacisk na specyficzne zjawisko i odnosząc się do szerszego kontekstu. Podejście takie wydaje się ze wszech miar słuszne i dobrze podsumowuje moje rozważania.

Muzyka rockowa, m.in. ze względu na rolę owego kontekstu, jawi się nam jako zjawisko kulturowe, społeczne czy historyczne, musi więc podlegać badaniom o charakterze interdyscyplinarnym. Wciąż jednak w centrum tego zjawiska pozostaje aspekt czysto muzyczny, dlatego też niezbędny dla uzyskania pełnego obrazu jest udział muzykologów w badaniach. Ważne jednak, by byli to właśnie muzykolodzy posługujący się odpowiednio zmodyfikowaną, nową metodologią.

\section{Bibliografia}

\section{Opracowania}

Castaldo G., Ziemia obiecana. Kultura rocka 1954-1994, tłum. J. Uszyński, Kraków 1997.

Covach J., From Craft to Art. Formal Structure in the Music of the Beatles, [w:] Reading the Beatles. Cultural Studies, Literary Criticism, and the Fab Four, red. K. Womack, T.F. Davis, Albany 2006, s. $37-53$.

Covach J., What's That Sound. An Introduction to Rock and Its History, New York-London 2009.

Cutler C., O muzyce popularnej, tłum. i oprac. I. Socha, Kraków 1999. Frith S., Sceniczne rytuały. O wartości muzyki popularnej, tłum. M. Król, Kraków 2011.

Hatch D., Millward S., From Blues to Rock. An Analytic History of Pop Music, Worcester 1987.

88 J. Covach, From Craft to Art. Formal Structure in the Music of the Beatles, [w:] Reading the Beatles. Cultural Studies, Literary Criticism, and the Fab Four, red. K. Womack, T.F. Davis, Albany 2006, s. 37-53. 
Kasperski J., Tożsamość muzykologii w perspektywie badań nad muzyka popularną, [w:] Kultura popularna w społeczeństwie wspólczesnym. Teoria i rzeczywistość, red. J. Drozdowicz, M. Bernasiewicz, Kraków 2010, s. 265-273.

Middleton R., Popular Music Analysis and Musicology. Bridging the Gap, „Popular Music” 12 (1993), s. 177-190.

Middleton R., Studying Popular Music, Philadelphia 1990.

Moore A.F., Analyzing Popular Music, Cambridge 2008.

Moore A.F., Rock. The Primary Text, Ashgate 2001.

Negus K., Popular Music in Theory. An Introduction, Cambridge 1999.

Piotrowski G., Zrozumieć krzyk. W stronę muzykologii rocka, [w:] A po co nam rock? Między dusza a ciałem, red. W. J. Burszta, M. Rychlewski, Warszawa 2003, s. 39-64.

Schoenberg A., Fundamentals of Musical Composition, LondonBoston 1970.

Shuker R., Popular Music. The Key Concepts, Oxon-New York 2006.

Shuker R., Understanding Popular Music, London-New York 1994.

Tagg P., Analysing Popular Music. Theory, Method and Practice, „Popular Music” 2 (1982), s. 37-67.

Siwak W., Estetyka rocka, Warszawa 1993.

Williamson N., The Rough Guide to the Blues, London 2007.

\section{Źródła muzyczne}

The Beach Boys, Good Vibrations, muz. i tekst B. Wilson/M. Love, Capitol 1966.

The Beach Boys, Surfin' Safari., muz. i tekst B. Wilson/M. Love, Capitol 1962.

The Beatles, Being for the Benefit of Mr. Kite!, muz. i tekst J. Lennon/P. McCartney, Parlophone 1967.

The Beatles, Happiness Is a Warm Gun, muz. i tekst J. Lennon/P. McCartney, Apple 1968.

The Beatles, Hey Bulldog, muz. i tekst J. Lennon/P. McCartney, Apple 1969.

The Beatles, Revolution 9, muz. i tekst J. Lennon/P. McCartney, Apple Records 1968.

The Beatles, She Loves You, muz. i tekst J. Lennon/P. McCartney, Parlophone 1963. 
The Beatles, Strawberry Fields Forever, muz. i tekst J. Lennon/P. McCartney, Parlophone 1967.

The Beatles, Think for Yourself, muz. i tekst G. Harrison, Parlophone 1965. Chuck Berry, Johnny B. Goode, muz. i tekst Ch. Berry, Chess 1958.

Chuck Berry, Rock and Roll Music, muz. i tekst Ch. Berry, Chess 1957. The Crazy World of Arthur Brown, Fire, muz. i tekst A. Brown/V. Crane/M. Finesilver/P. Ker, Track 1968.

Cream, Toad, muz. G. Baker, Polydor 1966.

Creedence Clearwater Revival, Proud Mary, muz. i tekst J. Fogerty, Fantasy 1969.

The Doors, Riders on the Storm, muz. i tekst J. Morrison/R. Krieger/R. Manzarek/J. Densmore, Elektra 1971.

The Doors, Strange Days, muz. i tekst J. Morrison/R. Manzarek/R. Krieger/J. Densmore, Elektra 1967.

Fats Domino, Blueberry Hill, muz. i tekst V. Rose/L. Stock/A. Lewis, Imperial Records 1956.

The Isley Brothers, Shout, muz. i tekst O. Isley/R. Isley/R. Isley, RCA 1959.

Jethro Tull, Living in the Past, muz. i tekst I. Anderson, Island Records 1969.

Louis Jordan \& His Tympany Five, Caldonia, muz. i tekst F. Moore, Decca 1945.

The Jimi Hendrix Experience, Hey Joe, muz. i tekst B. Roberts, Polydor 1966.

Ben E. King, Stand by Me, muz. i tekst B.E. King/J. Leiber/M. Stoller, Atco 1961.

King Crimson, 21st Century Schizoid Man, muz. i tekst P. Sinfield, Island 1969.

Led Zeppelin, Moby Dick, muz. J. Bonham/J.P. Jones/J. Page, Atlantic 1969.

Ramones, Blitzkrieg Bop, muz. i tekst T. Ramone/D.D. Ramone, Sire/ ABC 1976.

The Rolling Stones, Paint It Black, muz. i tekst M. Jagger/K. Richards, Decca 1966.

The Spencer Davis Group, Gimme Some Lovin', muz. i tekst S. Windwood/S. Davis/M. Windwood, Fontana 1966.

Muddy Waters, Got My Mojo Working, muz. i tekst P. Foster, Chess Records 1956. 
Muddy Waters, Hoochie Coochie Man, muz. i tekst W. Dixon, Chess Records 1954.

The Who, Baba O'Rile, muz. i tekst P. Townshend, Polydor 1971.

The Who, My Generation, muz. i tekst P. Townshend, Brunswick 1965. The Who, Pictures of Lily, muz. i tekst P. Townshend, Track 1967.

Howlin' Wolf, Somebody in My Home, muz. i tekst Ch.A. Burnett, Chess Records 1959.

Hank Williams, Hey, Good Lookin', muz. i tekst C. Porter, MGM 1951.

\section{Abstract}

\section{What shall we do with The Beatles? Methodology of musicology and rock music}

The article presents the possible input of musicologists in terms of popular music studies. It describes basic differences between rock and classical music, being still in the centre of attention of traditional musicology, and underlines the necessity of analysing musical recordings instead of relying on score music. New terminology is proposed - both original and based on Western scholars' experiences - especially relating to formal structure. The author also analyses different approaches to rhythmics (advocating that scholar himself needs to divide a song into bars), harmonics and melodics (presenting popular models), and instrumentation (underlining the importance of sound processing methods).

\section{Keywords}

rock music, popular music, methodology, musicology, The Beatles 